\title{
Managing clubroot disease (caused by Plasmodiophora brassicae Wor.) by exploiting the interactions between calcium cyanamide fertilizer and soil microorganisms
}

Article

Accepted Version

Dixon, G. R. (2017) Managing clubroot disease (caused by Plasmodiophora brassicae Wor.) by exploiting the interactions between calcium cyanamide fertilizer and soil microorganisms. Journal of Agricultural Science, 155 (4). pp. 527-543. ISSN 0021-8596 doi: https://doi.org/10.1017/S0021859616000800 Available at https://centaur.reading.ac.uk/68509/

It is advisable to refer to the publisher's version if you intend to cite from the work. See Guidance on citing.

To link to this article DOI: http://dx.doi.org/10.1017/S0021859616000800

Publisher: Cambridge University Press

All outputs in CentAUR are protected by Intellectual Property Rights law, including copyright law. Copyright and IPR is retained by the creators or other copyright holders. Terms and conditions for use of this material are defined in the End User Agreement. 


\section{www.reading.ac.uk/centaur}

\section{CentAUR}

Central Archive at the University of Reading

Reading's research outputs online 
3 Managing clubroot disease (caused by Plasmodiophora brassicae Wor.) by 4 exploiting the interactions between calcium cyanamide fertilizer and soil 5 microorganisms

\section{SUMMARY}

8 Calcium cyanamide is a nitrogenous fertilizer used predominantly for over a century in field 9 and glasshouse vegetable and salad production. This review draws together for the first time 10 knowledge concerning the biological properties of the compound that benefit crop production 11 by encouraging sustainable soil health and quality. This is achieved through the increase of microorganisms antagonistic to plant pathogens. The review also reports on the natural occurence and degradation of cyanamide. The literature survey provides a perspective of research from the early 1900 s to current studies. This identifies that nitrogen is released steadily into the rhizosphere from this fertiliser. Calcium is also readily available for plant roots and promotes the alkaline soil conditions beneficial to benign microorganisms.

17 Consequently, soil suppressiveness towards organisms such as Plasmodiophora brassicae, the cause of clubroot disease in brassicas develops. The effects of calcium and accompanying changes in soil $\mathrm{pH}$ values are discussed in relation to the life cycle stages of P.brassicae and the development of clubroot disease. Formulations of calcium cyanamide contain the dimeric

21 form, dicyandiamide (DCD). This compound slows soil nitrification and subsequent nitrate leaching into ground waters reducing potential pollution. Calcium cyanamide is normally used for specialised fresh produce production and is not available in quantities comparable 
with ammoniacal fertilizers. It is contended however, that it has properties deserving wider assessment because of their implications for sustainable cropping.

KEYWORDS: calcium cyanamide, disease suppression, microbial ecology, soil health, integrated pest management

Reconciling the need for producing sufficient high-quality, health-enhancing food for the world's expanding population with conserving biodiversity will be achieved through scientific and technological advances. Probably, two aspects of biology, breeding improved cultivars and enhancing the efficiency of nutrient uptake in partnership with soil microbes (Wissuwa et al. 2009) will be prominent among in these advances. Artificially supplementing nutrient supplies, especially nitrogen, has previously made major contributions in raising crop yields. For example, Bell et al. (1995) showed from long-term studies of cereal farming in the Yaqui Valley of Mexico that breeding improved wheat cultivars accounted for $28 \%$ of the overall farm yield progress and $48 \%$ came from increased use of nitrogenous fertilisers. This supports observations by Greenwood (1982) who showed that "in West Europe.....wheat yields are almost directly proportional to the level of $\mathrm{N}$-fertiliser applied“. It is now appreciated, however, that using nitrogenous fertilisers must not produce undesirable sideeffects such as nitrate pollution into river catchment areas (Sieling \& Kage 2010; Roy 2015). Ideally fertilizers should act in concert with soil-borne microbial populations as part of sustainable integrated pest management (IPM) strategies. This review suggests that calcium cyanamide, a specialized fertilizer which until recently has been used predominantly for intensive horticultural crops, has properties that could contribute to these IPM strategies including minimizing nitrate release into groundwater and encouraging benign soil-borne 
microbes (Miranda 1975; Dixon 2012a). In support of that contention this review examines the background to calcium cyanamide manufacture, the advantages and disadvantages of practical use, its presence as a natural metabolite, relationships with soil microorganisms and in particular capabilities for reducing the impact of soil-borne pathogens such as Plasmodiophora brassicae Wor., which causes clubroot disease.

\section{THE NITROGEN PROBLEM}

54 Sir William Crookes, an eminent chemist in the late $19^{\text {th }}$ century, highlighted the original "nitrogen problem", identifying that "the (artificial) fixation of nitrogen is vital to the progress of civilised humanity......." (Crookes 1900). For most of mankind's history, soil nitrogen was obtained from two natural sources, rainwater containing nitrous oxides derived from atmospheric electrical storms forming nitric acid and the activities of soil-borne bacteria either those in symbiotic relationships with legumes and other plants or those which exist as freely living forms. Farmers supplemented these sources with animal faeces either deposited directly onto pastures or as manure collected from farmyards. Other more minor sources included nitrogen bearing rocks in India and Chile plus deposits of guano, accumulated bird droppings, and waste materials such as shoddy, from some manufacturing processes. As Europe's Agricultural Revolution led on to its Industrial Revolution, finding new supplies of nitrogen that would boost food supplies became crucially important (this is reviewed in detail in textbook series by Broughton 1981, 1982, 1983, 1986). Research and industrial progress particularly in Germany developed at least six processes that artificially fixed atmospheric di-nitrogen $\left(\mathrm{N}_{2}\right)$ into stable forms in the late $19^{\text {th }}$ and early $20^{\text {th }}$ centuries. Three processes were economically feasible and commercialised:- the Norwegian Arc, the Haber- 
process has dominated nitrogen fertilizer manufacture for over a century. Production of calcium cyanamide has, however, continued predominantly for some specialised applications.

\section{CALCIUM CYANAMIDE}

74

From 1895 onwards, Adolph Frank (1834-1916) and Nikodemus Caro (1871-1935) researched chemical methods of nitrogen fixation as a means for making artificial fertilisers. Eventually working with, F. Rothe of Beringer Söhne they jointly discovered that calcium cyanamide could be made by the addition of pure di-nitrogen, prepared by air liquefaction (Linde 1916), to calcium carbide at temperatures in excess of $1000{ }^{\circ} \mathrm{C}$ (Frank 1908). In 1908 Frank and Caro established a factory near Trostberg, Bavaria, powered by hydroelectricity generated from the river Alz where they produced 30,000 tonnes per annum of calcium cyanamide by 1912 . This is now the most commonly used derivative of the cyanamide group of organic compounds with the general formula $\mathrm{CN}_{2} \mathrm{H}_{2}$. The molecule contains nitrile and amino groups. Hall (1905) working at Rothamsted Experiment Station, Harpenden (now Rothamsted Research) recognized calcium cyanamide as "the first attempt on a commercial scale to bring atmospheric nitrogen into a state of combination, to manufacture infact an artificial manure containing $\mathrm{N}$ derived from the air". The physical, chemical and industrial properties of the cyanamide group of compounds are discussed by Güthner \& Mertschenk (2006).

\section{FERTILIZER VALUE}

Originally this fertilizer was named Kalkstickstoff (nitrogen-chalk) and is also referred to as lime-nitrogen and nitrolime. It is now formulated as a granular dust-free product resulting from combination with calcium nitrate suspension, calcium carbonate and a surface treatment 
with wax. Calcium cyanamide (CASE Registry no: 420-02-4) contains approximately $20 \%$ nitrogen and $50 \%$ calcium (expressed as calcium oxide, $\mathrm{CaO}$ ). Albert Frank, son of Adolph Frank, demonstrated that in soil calcium cyanamide is converted into ammonium ions offering a form of artificial fertilizer nitrogen which plants could utilize (Anon 2008a ; Dixon 2009a). In Great Britain studies at Rothamsted demonstrated that soil microbial activity increases in the presence of calcium cyanamide (Ashby 1905) and in the USA by Jacob et al. (1924). Soil microbes slowly change calcium cyanamide in a step-wise process through cyanamide to urea to ammonia to nitrate (Bjälfe 1957). Alternatively and more rapidly carbonic acid from the atmosphere converts calcium cyanamide into cyanamide ions and calcium carbonate. Subsequent hydrolysis of cyanamide forms urea. In moist soils a proportion of cyanamide (6-11\%) dimerises into dicyandiamide (cyanoguanidin) $\left(\mathrm{H}_{4} \mathrm{C}_{2} \mathrm{~N}_{4}\right)$ (Cornforth 1971; Dixon \& Williamson 1985).

Dicyandiamide (DCD) is classed by the European Union (EU)-Fertiliser Directive 02003/2003 (Amendment of November $8^{\text {th }} 2008$ ) as a nitrification inhibitor. The initial DCD content of calcium cyanamide and additional amounts resulting from the effects of soil moisture and activities of microbes slows the rate of soil nitrification and reduces the leaching of nitrates into groundwater (Rathsack 1978; Vilsmeier \& Amberger 1978). Recent Japanese research (Yamamoto et al. 2012; 2013) demonstrated that calcium cyanamide reduces the emissions of nitrous oxide from soils. It is notable that nitrous oxide is a greenhouse gas which is estimated to be approximately 300 times more damaging for the environment than carbon dioxide (Solomon et al. 2007). Recent studies of spring applications of nitrogen fertilisers to winter wheat crops in eastern England emphasised the value of DCD in reducing nitrous oxide emissions (Thorman et al. 2014). In Germany, there is official recognition of DCD’s properties (Nömmik 1957; Anon 1996; Günther \& Mertschenk 2006). 
Bavaria, Germany. There are two factories in Japan and several in China. Limits on German production capacity mean that this fertilizer is available in modest quantities $(\sim 100,000 t / \mathrm{yr})$ for European users compared with the $450 \mathrm{Mt} / \mathrm{yr}$ of ammoniacal fertilizers produced by the Harber-Bosch process in factories worldwide (Smil 2004). This author identifies that artificial nitrogen production uses large amounts of energy. The Haber-Bosch process requires upto $2 \%$ of the world's annual energy supply while calcium cyanamide manufacture is one of the larger users of Germany's annual energy production (personal communication AlzChem, February 2015). The scale of calcium cyanamide production is also limited by the two-stage nature of chemical manufacture which initially involves carefully forming calcium carbide. After manufacture the finely ground product is compacted by a granulation process resulting in very hard fertilizer granules. Treating the surface of these granules with a wax ensures that the fertilizer product is a dust-free formulation. In this state the product has an unlimited storage life (Güthner \& Mertschenk 2006) and may be transported without restriction, packed in polyethylene valve or multilayer paper bags.

The relatively modest scale of production means that the cost of calcium cyanamide is preportionately higher than ammonia-based products. But since this fertilizer combines nitrogen and calcium, the latter reducing the need for applications of lime and helping to diminish the impact of soil-borne pathogens eliminating some other resource purchases. The agronomic value of calcium cyanamide is increased by repeated use over several seasons which further increases yields and crop health (Crowther \& Richardson 1932; Verona 1970). and salad crops in Europe, Asia and North America. Use in other crops has strengthened recently because of increased applications on oilseed rape crops in Northern Europe where 
144 China is also increasing for similar reasons because of their substantial problems with clubroot disease ( $P$. brassicae) on oilseed rape and vegetable brassica (Brassica rapa) crops which are a staple part of the diet (Chai et al. 2014). The properties of calcium cynamide for inhibiting seed germination (Sturkie 1937) resulted in earlier recommendations for a 14-day interval between application and drilling. This restriction is less necesary for transplanted crops where recommendations, for example in Harling \& Oxley (2007) suggest applying split applications of $500 \mathrm{~kg} / \mathrm{ha}$ as a base dressing followed by a further $500 \mathrm{~kg} / \mathrm{ha} \mathrm{14-21} \mathrm{days}$ after transplanting modules. Recent technological advances in crop husbandry permitting between-row, in-row and deep-placement of fertilizers now relaxes these restrictions further because the volumes of fertilizers applied per unit area are greatly reduced while nutrient-use efficiency increases (Burns et al. 2010). In Australia Donald et al. (2004) demonstrated the usefulness of banding techniques for the application of calcium cyanamide which reduced clubroot incidence and costs. This technique is especially useful in Asian vegetable brassica crops grown on soils with high organic matter contents where clubroot disease can be particularly devastating (McDonald et al. 2004).

\section{Stability in soil}

Long-term studies in Portugal (1958-1974) compared the effects of applying ammonium nitrate, ammonium sulphate, calcium cyanamide, calcium nitrate and urea to land in a warm temperate region with an annual average rainfall exceeding 1,100 mm (Miranda 1975). The $\mathrm{pH}$ of calcium cyanamide treated plots increased slightly in alkalinity while the other treatments raised soil acidity. Additionally, the use of calcium cyanamide resulted in greater retention of exchangeable calcium while other fertilizers reduced it. The phosphate and potash content of soil treated with calcium cyanamide remained stable with increased availability of these nutrients. 
Subsequent research in a tropical environment subjected coarse textured kaolinitic ultisol placed in soil columns and treated with calcium cyanamide, urea or calcium ammonium nitrate to the equivalent of 2,420 mm rainfall over 42 days (Pleysier et al. 1987).

172 Lowest leaching losses (3\% of the nitrogen applied) were recorded where calcium cyanamide was used, highest losses were found with calcium ammonium nitrate while urea produced intermediate effects. These results indicated that calcium cyanamide is retained in soils and is not leached even where rainfall or irrigation is substantial. These are valuable properties in relation to the use of irrigation and spread of plant pathogens (Dixon 2015). The nitrate content of soils treated with calcium cyanamide was lower than those of untreated controls (Nõmmik 1958). This research showed that conversion to nitrate took longer where calcium cyanamide was used compared with ammonium sulphate. Soil texture influenced the rate of conversion, with coarse sandy soils retaining nitrate longer. In soil samples incubated for 3 months, more than $90 \%$ of the nitrogen was retained in the calcium cyanamide treatments. Lowering the temperature slowed nitrification still further. The conversion of calcium cyanamide to ammonia was stopped in sterilized soil, indicating that this process requires microbially derived enzymes. Earlier research by Jacob et al. (1924) produced broadly comparable results.

The fertilizer properties of calcium cyanamide were reviewed by Rieder (1981) and more recently by Dixon (2009a; 2012a). These workers identified that granulating calcium cyanamide increased its stability and environmental value. Granulation of calcium cyanamide improved its fertilizer-use-efficiency and availability for roots (Vilsmeier \& Amberger 1978). Amberger $(1986 ; 1989)$ also demonstrated that when DCD inhibits the initial step in nitrification, this conserves nitrogen as ammonium $\left(\mathrm{NH}_{4}^{+}\right)$ions. Dicyandiamide ultimately is 
decomposed by biotic and abiotic processes in soils into ammonium ions, carbon dioxide and water, while nitrogen is slowly released.

\section{NATURAL OCCURRENCE AND UTILISATION OF CYANAMIDE}

Hairy vetch (Vicia villosa), which originates from Europe and Western Asia, is used as a cover crop in the USA as a means of protecting land from wind and water erosion during fallow periods (Hartwig \& Ammon 2002). This legume adds nitrogen into the soil and is also antagonistic to weed growth, suggesting that it may produce naturally growth-inhibitory compounds. Analyses by Kamo et al. (2003) showed that hairy vetch produces cyanamide, which has allelo-chemical activity against lettuce (Lactuca sativa) seedlings used as test plants. Germinated seedlings of hairy vetch contained 40 -fold greater concentrations of cyanamide compared with the content of dry seed, illustrating that this plant generates cyanamide during its early growth. In hairy vetch seedlings, concentrations of cyanamide as high as $130 \mu \mathrm{g} / \mathrm{g}$ fresh weight were found. This illustrates that cyanamide, which was previously considered solely as a product of industrial manufacturing, is also a naturally occurring metabolite. Later studies by Kamo et al. $(2006 ; 2012)$ indicated that young leaves of V. villosa, V. cracca, V. benghalensis and Robinia pseudo-acacia contained cyanamide $\left(\mathrm{NH}_{2} \mathrm{CN}\right)$ in the range of 190 to $645 \mu \mathrm{g} / \mathrm{g}$ fresh weight determined by gas chromatographymass spectrometry (GC-MS).

Some Aspergillus and Penicillium spp can utilise the cyanamide molecule as a source of nitrogen for decomposing cellulose (Klasse 2002). Consequently, calcium cyanamide is considered as "an environmentally benign product as it is broken down to harmless products by microbes" (Harling \& Oxley 2007). The soil-borne fungus Myrothecium verrucaria is capable of degrading fertilizer calcium cyanamide by the action of a single soluble enzyme 
that hydrolyses cyanamide to urea (Stransky \& Amberger 1973). Cyanamide hydratase is produced by this fungus in combination with an urease (Maier-Greiner et al. 1991; LehtovirkMorley et al. 2011; Tourna et al. 2011). The discovery of this highly substrate-specific cyanamide hydratase, the elucidation of its structure as a homo-hexameric polypeptide, and the isolation of its gene $(c a h)$ offers the possibility that transformed plants could carry out these reactions. That would allow calcium cyanamide fertilizer to be applied before sowing without risking seedling growth inhibition. This could reduce the amount of fertilizer calcium cyanamide required while retaining its effectiveness as a source of nitrogen. Other suggestions (Wood 1998) that would improve the efficacy of calcium cyanamide fertilizer applications have been the incorporation of the cah gene into crop plants so that they could directly utilize cyanamide as opposed to requiring its initial conversion to urea.

\section{SOIL HEALTH AND FERTILISER VALUE}

Sustainable agriculture aims at developing healthy soils, as discussed by Lehmann \& Kleber (2015) and Wall et al. (2015). Healthy soils are stable systems in which there are high levels of biological diversity, activity, internal nutrient cycling and resilience to disturbance (Doran et al. 1996; Doran \& Zeiss 2000; Eveillard 2005;Bruggen et al. 2006). Soil health is defined in detail by Pankhurst et al. (1997) and by the United Nations Food and Agriculture Organisation (Anon 2008b). Retaining the diversity of microbes in soil is critical for maintaining soil health and quality and the wide range of microbes involved in soil functioning (Liesach et al. 1997; Garbeva et al. 2004). This preserves the huge genotypic and phenotypic diversity, heterogeneity and crypticity in soil microbial populations. The top layer of soil may contain up to $10^{9}$ microbe cells per gram (Torsvik \& Ovreas 2002). As yet knowledge concerning many of these organisms and their interactions is limited. The fraction 
of cells making up the general microbial biomass that have been cultured and studied is very small, probably less than $5 \%$ (Torsvik et al. 1990; Borneman \& Triplett 1997). An added difficulty is that microbe populations may change quite rapidly during cropping especially, where soluble nutrients such as ammonium-nitrogen are used and soil acidity increases (Kirkby 1968). Consequently, where possible practical fertilizer strategies should aim at encouraging beneficial microbes especially those that are antagonists against soil-borne pathogens (such as P. brasicae) (Lahlali \& Peng 2014; Zhao et al. 2015).

Müller (1955) was one of the first pathologists who associated calcium cyanamide with reductions in diseases caused by soil-borne microbes. She also recorded its effects stimulating the growth of non-pathogenic microbes. Earlier interactions between calcium cyanamide and soil microbe populations had been reported by Allison (1924), Kuen \& Drecksel (1928), Wolfe \& Wolfe (1930) and Haenseler \& Moyer (1937). The detailed studies by Haenseler \& Moyer (1937) demonstrated that bacteria and actinomyces populations in soil initially decreased and then rapidly accelerated for about 30 days after applications of calcium cyanamide. Thereafter numbers dropped returning to the values present before the fertilizer was applied. At their peak, however, the numbers of microbes in these two groups were 90-fold greater compared with normal soil content. Similar results are reported more recently by Klasse (1996). Applications of calcium cyanamide are associated with increased extracellular enzyme activity in soil, which is indicative of enhanced microbial activity (Bosch \& Amberger 1983). These included increases in: biomass, amylase, protease, alkaline phosphatase and dehydrogenase activities, exceeding that achieved by applications of farmyard manure and ammonium sulphate. This implies that for organic husbandry systems, the use of calcium cyanamide is superior in its effects to those obtained from animal manure (Zhu et al. 2001). 

were highlighted by Cornforth (1971), Rieder (1981) and Klasse (1999). Evidence for the benefits of fertilisers like calcium cyanamide in developing healthy soils is accumulating. In China, for example, large areas of land are now devoted to the production of protected vegetables, especially cucumbers, tomatoes and aubergines. This has lead to a rise in crop losses caused by soil-borne pathogens, especially fungi such as Verticillium spp. Calcium cyanamide applications increased the biological health of these soils and resulted in improved crop growth by inducing shifts in the composition of microbial communities (Tian et al. 2009). This reduced the damage from Verticillium spp. Calcium cyanamide increased mineral nitrogen, followed by increased microbial biomass, especially in the autumn periods. Similar findings are reported by Shi et al. (2009) where calcium cyanamide applications increased soil bacterial populations and decreased the pathogen Fusarium oxysporum $\mathrm{f}$. sp. cucurbitae (cucurbit wilt). Subsequently, reductions of activity by the soil pathogen $F$. solani f. sp. cucurbitae (stem rot) affecting cucumber was ascribed by Bourbos et al. (1997) to soil enrichment with nitrogen and calcium. Bletos (2006) suggested that calcium cyanamide can form an effective component of an integrated management system, which eliminates the need for using the environmentally damaging sterilant methyl bromide. bacteria increased in soil treated with calcium cyanamide, while those of fungi decreased in the 30 days after application. This, they claim restored the microbial community balance to a healthy status favorable for vegetable cropping. Use of polymerase chain reaction-denaturing gradient gel electrophoresis (PCR-DGGE) fingerprinting indicated that the bacterial populations following calcium cyanamide application changed with the appearance of new species and increased biodiversity. The diversity and richness indices 20 days after calcium cyanamide was applied increased substantially. The dimer product dicyandiamide (DCD) 
produced similar effects, improving diversity and richness in bacterial populations. These

292

293

294

295

296

297

298

299

300

301

302

303

304

305

306

307

308

309

310

311

312

313

314

315 authors suggested that such effects are principal mechanisms by which the cyanamide fertiliser reduced the impact of soil-borne pathogens. Greater knowledge of the interaction of fertilizers and microbes might also solve some of the problems highlighted by Walters et al. (2013) regarding the use of induced resistance as an ingredient in integrated disease management strategies. Since calcium cyanamide provides a readily available source of calcium for plants, potentially this may help up-regulate aspects of general and specific resistance, as suggested by Takahashi et al. (2002). In these studies an influx of calcium into turnip cells increased the formation of phenylalanine ammonia-lyase (PAL) activity, which appeared necessary for the expression of resistance to Plasmodiophora brassicae. As Dixon \& Tilston (2010), suggest knowledge of the properties of fertilizers such as calcium cyanamide might help redirect agronomists towards enhancing soil and plant health.

(1)

\section{CALCIUM CYANAMIDE AND THE SUPPRESSION OF CLUBROOT DISEASE}

Clubroot disease is caused by the protist member of the Rhizaria (Burki et al. 2010; Neuhauser et al. 2011; Schwelm et al. 2015) Plasmodiophora brasicae, a microbe which attacks members of the Brassicaceae family. Clubroot is an intractable disease affecting this group of crops, which are vitally important sources of fresh and processed vegetables and oil seeds. These crops contain chemicals that are associated with significant improvements in human health. They also provide cooking oils and fats, industrial lubricants, lighting fuels, condiments and flavourings, animal fodder and forage, improved soil fertility and bio-control, while also including ornamental decorative annuals and perennials. Arabidopsis thaliana (thale cress) which is the molecular biologists' main model species and the first plant whose 
genome was sequenced, is also included in this family (Dixon 2007) and suffers from clubroot disease making it a valuable source of information on host-parasite relationships and potentially increasing the pool of resistance genes (Alix et al. 2007). Advances in understanding the biology of this host-pathogen relationship were described by Dixon (2006 2014). The economic significance, impact and biology of this pathogen are reviewed by Dixon (2009b,c; 2014).

\section{Disease incidence}

It is evident from the very earliest scientific studies of clubroot and its causal organism $P$. brassicae in the $19^{\text {th }}$ century by Woronin (1878 translated by Chupp 1934) that there were associations between fertilizer-use and the incidence and suppession of disease. Woronin, however, could not verify these assertions scientifically. Calcium cyanamide has gained an association for reducing the impact of clubroot disease over the past 100 years. The early studies of the relationship between soil borne pathogenic microbes and calcium cyanamide showed that regular applications of the fertilizer were associated with reductions in the occurrence and severity of clubroot. Research by Martin (1933) reported considerable reductions in clubroot disease following applications of calcium cyanamide. Subsequently, Walker \& Larson (1935) emphasised the influence of soil conditions in moderating its efficacy, but demonstrated that weight-for-weight, the effect of calcium cyanamide exceeded that of lime (calcium carbonate) by a factor of two. Haensler \& Moyer (1937) showed in both field and laboratory studies that applications of calcium cyanamide were associated with reductions in the incidence of clubroot disease. Calcium cyanamide was shown by them to have 2.5-fold greater impact in reducing clubroot compared with hydrated lime. Importantly, 
environment. Small changes in $\mathrm{pH}$ values, soil moisture content, structure and texture affected the level of disease reduction. This served to underline the importance of Crowther and Richardson's (1932) findings that hydrogen-ion concentration in soil regulated the breakdown reactions of calcium cyanamide. The importance of interactions between soil environments, modes of application and the incidence of clubroot disease and its severity are discussed by Colhoun (1958) and Karling (1968) in their respective monographs. In farming practice, calcium cyanamide was used regularly for vegetable crops in Great Britain during the 1920s and 1930s (Smith 1961 and personal communication from Dr Elizabeth Gray $12^{\text {th }}$ August 1985).

Following the World War II scientific interest in interactions between fertilizers and the reduced severity of soil-borne diseases was largely overtaken by the invention of numerous synthetic agrochemical molecules. These eliminated specific pathogens by inhibiting single enzyme-driven reactions. Attempts at control of clubroot followed this route with reports of extensive testing of synthetic chemicals for example Buczacki \& Cadd (1976). More environmentally sensitive approaches returned in the 1980s. Researchers, farmers and growers began recognising that reducing clubroot disease would be achieved only by integrated pest management (IPM). This combined genetic resistance with the manipulation of soil environments, host nutritional status and where possible use of synthetic agrochemicals. In the period between 1945 and the early 1980s, practical use of calcium cyanamide as a specialized fertilizer in horticulture continued, particularly in north-western Europe. Here it was associated with higher crop health status and increased soil fertility (Rieder 1981). Studies restarted in Great Britain in the early 1980s when it was demonstrated that calcium cyanamide is associated with reductions in the severity of clubroot disease 

in swede (B. napus) cultivars of differing resistance to $P$. brassicae. Disease severity was progressively reduced when increasing amounts of calcium cyanamide were applied. Disease threshold was related to the viable inoculum density, cultivar resistance and the use of calcium cyanamide. The integrated use of calcium cyanamide with boron and forms of nitrogen resulted in the lessening of clubroot severity (Dixon et al. 1987). Calcium cyanamide is reported by Horiuchi et al. (1983) as a useful component when integrated with solarisation as a means of reducing inoculum load in $P$. brassicae infested land. Similarly, Dixon \& Wilson (1983) reported on the successful use of calcium cyanamide in reducing the impact of clubroot on cabbage and Brussels sprouts. This was followed by detailed multi-site and -seasonal studies that estimated the reduction in clubroot disease following the use of calcium cyanamide fertiliser achieving a minimum of $30 \%$ improvement in yields (Humpherson-Jones et al. 1992). At the same time calcium cyanamide was associated by Naiki \& Dixon (1987) with the diminution of disease severity caused by P. brassicae when examined in controlled environment and glasshouse experiments. Reductions in disease severity were related to the interval between application of the fertilizer and planting of susceptible Chinese cabbage (B. rapa spp. pekinensis cv. Granaat) seedlings in pathogen infested soil. Calcium cyanamide also stimulated host growth at all the treatment concentrations used. Subsequently, associations between the use of calcium cyanamide and reductions in the incidence of clubroot disease ( $P$. brassicae) of brassicas is reviewed by Dixon (2009a; 2010; 2012a) Australian vegetable brassica industry, most notably cauliflower and calabrese (green broccoli) crops in Victoria and Western Australia. A system of integrated control was developed which included the use of calcium cyanamide. Applying the fertilizer by banded 
applications directed into the crop rows planted on raised beds significantly reduced cost by cutting application rates by $66 \%$ and reduced the level of disease incidence. The marketable yield of calabrese receiving calcium cyanamide was double that of untreated controls in both 1996 and 1997 in Victoria indicating that crop growth was improved. This followed earlier work which studied the particle size and application methods for calcium cyanamide used in Australian vegetable production (Donald et al. 2004). These studies showed that calcium cyanamide used with other treatments, especially rapidly acting forms of lime successfully reduced the intensity of clubroot disease in the field (Donald et al. 2006). Subsequent British studies (Harling et al. 2007; Stewart 2007) indicated that combining calcium cyanamide with other bio-fertilizers and formulations of calcium was associated with reductions in clubroot disease on several sites over four seasons.

The Australian workers also developed a real-time polymerase chain reaction (PCR) test that quantified inoculum loads and allowed predictions of yield losses (Donald et al. 2006). There is a minimum viable spore density of between $10^{3}$ and $10^{4}$ spores per gm of dry soil before root hair infection by $P$. brassicae leads to consistent disease expression suggested Naiki et al. (1978). This result agrees with Garrett's (1958) theories of minimal inoculum potential being required before there is successful disease development caused by soil-borne pathogens.

Integrated use of calcium cyanamide with lime is advocated by Belec et al. (2004) in Canada and with the addition of resistant cultivars into an integrated system was recommended for vegetable brassicas (Anon 2012). Similar reports come from other centres in Canada (McDonald 2002). Working on highly organic muck soils in Ontario, she found that calcium cyanamide applications were strongly associated with reductions in clubroot severity especially when used in combination with applications of boron. The need for coherent means for controlling clubroot disease is highlighted by information now coming 
from China. Reportedly 70 to $80 \%$ of land used for brassica crops, which are of major culinary and industrial significance in the provinces of Guangdong, Shandong, Zhejiang,

417 Jiangsu, Hangzhou, Jinhua, and Nongbo district of Zhejiang province, is infested with $P$. 418 brassicae (Chai et al. 2014). This poses a problem of great urgency for Chinese agriculture. 419 Lime-nitrogen (calcium cyanamide) applications were associated with substantial reductions 420 of clubroot disease in Chinese cabbage, increased yield and grower's income (Benyue 1995) Clubroot severely limits brassica crop production worldwide and has now gained major footholds in the oilseed rape crops of Canada, China and northern Europe, threatening the viability of one of the world's most significant internationally-traded crops (Strelkov \& Dixon 2014). Management of P. brassicae is limited by the factors discussed by Dixon (2014). The distribution of this pathogen seems to be increasing since disease reports are now coming from countries which previously had no or very limited occurrence of clubroot such as Turkey (Apaydin et al. 2010).

Mode of action

The association of calcium, in the form of lime, with the suppression of clubroot (finger and toe) disease was well established even before the causal organism was identified (Anon 1853). Thereafter calcium as limes or to a lesser extent fertilizers such as calcium cyanamide were recommended as practical means for reducing the progress of clubroot disease (Colhoun 1958; Karling 1968). The mode of action of calcium and associated effects on soil pH has, however, been elucidated only relatively recently. Fletcher et al. (1982) recognised that 437 although $\mathrm{pH}$ influenced the progress of clubroot disease, this was affected by the 438 concentrations of calcium ions in the soil solution. In California, USA., Campbell et al. 439 (1985) concluded that there was an interaction between $\mathrm{pH}$, extractable calcium and 
magnesium, which must exceed approximately $14 \mathrm{meq} / 100 \mathrm{mg}$ of soil from native minerals or with fertilizers, such as calcium cyanamide or lime treatments. These relationships were studied by Dixon \& Webster (1988) and by Webster and Dixon (1991 a, b) who demonstrated details of the stages in the life-cycle of $P$. brassicae and the associated development of pathogenesis that are regulated by calcium ions, $\mathrm{pH}$ values and host factors. Each of these components, while affected by the others, has independent effects. These operate throughout the pathogen life-cycle from the germination of motile primary zoospores, penetration and colonisation of root hairs through the formation of primary plasmodia, sporangia and then onto the infection of cortical cells and the secondary stages of pathogenesis which culminate in gall formation. Increasing soil calcium or alkalinity reduces the rate of maturation of $P$. brassicae in root hairs retarding its the speed and the quantities of plasmodia which formed sporangia. But as Myers \& Campbell (1985) demonstrated, calcium has little impact on the dormant resting spores. Previously, Macfarlane (1958) had demonstrated that in controlled experiments $\mathrm{pH}$ values of 5 to 6 had little influence on the level of successful infection by primary zoospores penetrating root hairs. Successful infection diminished greatly as $\mathrm{pH}$ increased and reached 8.0. This effect was further explained by Donald \& Porter (2004) who showed that at acidic $\mathrm{pH}$ values the progress of infection into root hairs was only delayed by the presence of significant amounts of calcium $(20 \mathrm{mM})$. As $\mathrm{pH}$ became increasingly alkaline, the amount of calcium required to reduce root hair infection lessened. Subsequently Takahashi et al. (2006) found that when P. brassicae encounters resistant cultivars, there is an alkalisation of the environment in the rhizosphere which retards the capacity of the pathogen for invasion. He found that cell death in Arabidopsis thaliana resistant to $P$. brassicae was associated with increasing alkalisation of the root environment and that this did not occur in cultures of susceptible plants. These suggestions were taken further by Niwa et al. (2007) who emphasised the role of $\mathrm{pH}$ in moderating the development 
of clubroot disease in field experiments. Soils which were suppressive of $P$. brassicae had elevated calcium contents and alkaline $\mathrm{pH}$ and considerable microbial activity. Webster (1986) found that nitrate-nitrogen could also be associated with reduced root hair invasion by P. brassicae . At least in part this might be explained by findings that on root surfaces there is a localised increase in $\mathrm{pH}$ associated with nitrate-nitrogen and a decline in $\mathrm{pH}$ around root hairs when ammonium is the source of nitrogen (Marschner et al. 1986). understood. Yano et al. (1991) investigated by quantitative analysis the relationships between calcium in spore suspension and effects of inoculation in culture solutions with resting spores. Their results suggested that the presence of calcium (as $\mathrm{Ca}^{2+}$ ions) promoted the germination of $P$. brassicae resting spores. That exposes the resultant delicate primary zoospores to predation by soil-borne bacteria and may also reduce their motility. By analogy with the water moulds (Oomyces), that also rely on flagella for motility, calcium ions in solution adversely affect the movement of zoospores (Donaldson \& Deacon 1993). Yano's research offered a clue to the manner by which microbial populations antagonistic towards $P$. brassicae might be stimulated by the presence of calcium.

The volume of soil where $P$. brassicae most probably encounters greatest numbers of anatagonistic microorganisms is the rhizosphere. This is because the primary zoospores are less than $1.5 \mu \mathrm{m}$ diameter (Cook 1933) and hence will have limited supplies of energy and not be capable of moving far in soil moisture films from the resting spore to the host root surface (Dixon 2014) in response to host root exudates (Mattey \& Dixon 2015). It is the suppressive or conducive environment in the rhizosphere which $P$. brassicae zoospores encounter as they 
attempt penetration of the root hairs which determines the success or failure of subsequent invasion and disease development. A generalised description of the rhizosphere was provided by Hinsinger et al. (2005). This emphasised its complexity since it is occupied by beneficial as well as pathogenic organisms and plant root systems. Further, the rhizoplane (root surface) and surrounding rhizosphere were noted by Newton et al. (2010) as "support(ing) complex microbial communities that can influence nutrient availability and the ability of pathogens to colonise roots". This complexity in the microbial community and resultant suppressitity or conduciveness is influenced by agricultural practices as discussed by Raaijmakers et al. (2009) and Raaijmaaker \& Mazzola (2016). This encourages beneficial rhizosphere microorganisms such as the bacteria Pseudomonas, Burkholderia and Bacillus which adversely affect the population density, dynamics and metabolic activities of soil-borne pathogens (Raaijmakers et al. 2009). Increasing the activities of microorganisms capable of suppressing pathogens is a route by which sustainable husbandry may be achieved as advocated by Mazzola (2004) particularly in relation to take-all disease of cereals (Gaeumannomyces graminis). Research with various soil amendments indicates that stimulation of soil microbial populations encourages chitinolytic bacteria which are capable of degrading the resting spores of $P$. brassicae because they contain chitin in the cell wall (Buczacki \& Moxham 1983). The stimulation of chitinolytic bacteria resulting in the inhibition of diseases caused by soil-borne pathogens is discussed by Dixon \& Walsh (1998) The indirect effects of calcium cyanamide, of stimulating antagonistic microbe populations, which then results in reduced incidence of soil-borne pathogens and the diseases that they incite was identified for Verticillium albo-atrum, Pythium ultimum and

512 Thielaviopsis basicola by Verona (1970). Applications of calcium cyanamide were 513 demonstrated by Huang \& Sun (1991) to be associated with encouraging bacterial 514 populations in treated soil and in reductions in populations of some other plant pathogenic 
fungi such as Sclerotinia sclerotiorum a cause of white rot in a wide range of crops (Jones \&

516 Gray 1973). Applying calcium cyanamide to soil also encouraged suppressiveness towards $F$.

517 oxysporum f. sp. cucumerinum (cucumber wilt) (Shi et al. 2009). It was suggested by Horiuchi et al. (1983) that calcium cyanamide enhanced the suppression of clubroot in association with the use of soil solarisation.

Studies of soil-borne bacteria such as Bacillus subtilis established that they are antagonists of $P$. brassicae (Einhorn et al. 1991). In the 1980s in Taiwan Hsieh \& Wang (1986) examined the components of clubroot suppressive soils. They concluded that while calcium and $\mathrm{pH}$ were important factors the stimulation of populations of antagonistic microbes was also essential. In Taiwan, clubroot suppressive soils were associated with $\mathrm{pH}$ values $>7.4$ and with a calcium content of $>1210 \mathrm{ppm}$. The local irrigation water was found by Hseih \& Wang (1986) to be highly calcareous but they contended that suppressivity was partially related to soil physico-chemical factors such as texture, $\mathrm{pH}$, organic matter content and exchangeable potassium, sodium, magnesium and calcium. But acidifying soils, which is a means of removing bacteria was shown by Wang \& Hsieh (1986) to reduce their suppressive properties.

Applications of calcium cyanamide were associated with increased numbers of microbes in soil (Allison 1924; Mukerji 1932). Soil biological health as measured by the amount of amylase and protease activity increased where calcium cyanamide was used, whereas the opposite effects were obtained with applications of ammonium sulphate (Bosch \& Amberger 1983). Calcium hydroxide may be released from calcium cyanamide, which then raises alkaline soil $\mathrm{pH}$, further encouraging microbial activity and benefiting soil fertility (Verona 1970). The subsequent release of nitrogen via DCD encourages populations of heterotrophic microbes (Nõmmik 1958). Overall, the breakdown of calcium cyanamide increases the heterogeneity of soil microbe populations and in turn this raises fertility. This 
540 finding supports the early results of Crowther \& Richardson (1932) showing that calcium 541 cyanamide is most effective when applied as routine annual applications thereby maintaining 542 environments conducive for increased microbial activity. More recently studies in Brittany by Rouxel et al. (1985) of conducive and suppressive soils established a relationship between $\mathrm{pH}$ values, soil moisture, inoculum load and clubroot disease. He also speculated on the role which microbial biological control agents might play and their interaction with physical characteristics of soil. Page (2001) clearly demonstrated that applications of calcium in various forms of lime could be associated with the development of soil suppressivity towards P. brassicae. Her Scottish field studies identified the development of soil suppressiveness towards $P$. brassicae resulting from the interactions between calcium and benign soil microbes. This relationship was explored further by Murakami et al. (2002) identifying the effects of reducing inoculum load as suppressiveness increased resulting in reduced disease expression associated with exchangeable soil calcium. A link between calcium and increased microbial activity was developed by Niwa et al. $(2007 ; 2008)$ in relation to suppressive and conducive soils. They demonstrated that calcium is associated with increased microbial activity and reduced germination of $P$. brassciae resting spores and in turn this suppresses the development of clubroot disease. They demonstrated that soil borne microbes may change their metabolic activities when calcium cyanamide is present. The diversity and species richness of soil populations of beneficial bacteria was enhanced by calcium cyanamide as Niwa et al. (2008)

560 demonstrated by increasing amounts of rRNA fragments. Subsequently, (Junwei et al. 2013) reported that applications of calcium cyanamide encourages soil bacterial community diversity and richness. Potentially that could increase soil suppressiveness and probably result in a decline in soil-borne plant pathogens. If suppressiveness is accepted as a component of soil health then that also implies promoting a broader spectrum of soil inhabitants such as 
earthworms. The report by Bauchheno (1994) then becomes relevant. This work demonstrated that applications of calcium cyanamide caused no adverse effects on

567

568

569

570

571

\section{2}

573

574

575

576

577

578

579

580

581

582

583

584

585

586

587

588

populations of several earthworm species and ultimately resulted in increased numbers of these animals. It is also noted that beneficial bacteria such as nitrogen-fixing bradyrhizobia are increased by the presence of calcium cyanamide. Nitrogen fixation, for example, was 50 $\%$ greater in soybean crops receiving this fertilizer (Tewari et al. 2004).

\section{DISCUSSION AND CONCLUSIONS}

(1)

Immense challenges will face scientists, farmers and growers over the next 50 years in ensuring food security as human populations expand, land areas for cropping diminish and water supplies for irrigation are becoming restricted (Dixon 2009d; 2012b). Confronting these challenges requires larger crop yields without accelerating climate change, soil degradation, water shortages or the further impoverishment of natural biodiversity. Currently, agricultural productivity increases by about $2 \%$ annually as a result of scientific improvements, this must rise to $3 \%$ if food security worldwide is to be maximised (Braun 2010; Dixon 2009d; 2012b). Raising the intensity of production should be linked with the protection of the environment (Tollefson 2010) in which soil management will be of particular importance (Schutter et al. 2001; Bronick \& Lal 2005). Consequently, the potentialities of currently relatively minor husbandry tools such as specialised sources of crop nutrients like calcium cyanamide should be assessed. Research of this nature is called for by Frank \& Groffman (2009) in their challenges asking for more information concerning the movement and uptake of nitrogen from the rhizosphere into roots. It is also highlighted by Paustian et al. (2016) specifically in relation to improved fertiliser-use-efficiency. 

nitrogen. While the quantities currently produced are far less than those made using the

591 Harber-Bosch process it has retained a market presence for over a century. During that time 592 the uses of calcium cyanamide have mainly centred on specialised applications for high-value 593 field and glasshouse vegetable and salad crops. Here it has been associated the promotion of soil health and quality, and reducing the impact of soil-borne pathogens such as $P$. brassicae, (Dixon et al. 1987) or species of Sclerotinia. Additionally, the presence of the dimer DCD in the commercially formulated fertilizer and its formation in soils treated with calcium cyanamide reduces nitrification and slows nitrate pollution. Properties of this fertilizer for slowly releasing nitrogen into the rhizosphere linked with the ready availability of calcium encourage the development of microbial diversity and suppressiveness towards soil-borne pathogens. The latter property in particular, is encouraging interest in calcium cyanamide for application in oilseed rape crops which are now increasingly damaged by clubroot disease (Dixon 2010; Diederichsen et al. 2014). Consequently, there is wider recognition of calcium cyanamide as a potentially valuable component of environmentally sustainable integrated pest management (IPM) strategies for this destructive disease worldwide as suggested by Tremblay et al. (2005) and Donald \& Porter. (2014). This strategy involves encouraging suppressive soils containing microorganisms that are antagonistic towards soil-borne pathogens. (Dixon \& Tilston 2010). Developing soil suppressiveness towards P. brassicae is an established technique following studies such as those of Arie et al. (1998), Einhorn et al. (1991) and Lahlali et al. (2014 a,b). Increasingly, accurate means for targetting such fertilizers into the root zone are becoming available following the development of automated robotic sensing of varying fertilizer requirements across crops through changes in foliar nitrogen status (Gianquinto et al. 2003) combined with increased efficiency in granule 
613 distribution into the canopy (Antille et al. 2015). With potential increases in efficacy and cost 614 savings. As a result the cost is likely to be reduced and efficacy increased. welfare for over a century. This role in crop husbandry is likely to continue, but the manner by which this is achieved will be modified as needs for sustaining environmental security, biodiversity and human health increase. There are already requirements for protecting Nitrate Vulnerable Zones (NVZs) and the dangers of raised nitrate concentrations in crops (Pimpini et al. 1970) have been long recognised. Consideration should be given to using nitrogen fertiliser formulations that are not accompanied by these problems (Sieling \& Kage 2010) and which encourage beneficial microorganisms (Yao et al. 2000). That improves soil health and quality which is internationally recognised as means for increasing agricultural productivity and conserving and sustaining biological diversity. Increasingly multidisciplinary research is providing knowledge which will enable improved exploitation of the benefits offered by benign soil inhabiting microbes in the repair and maintenance of soil 627 health.

Agriculture is the sector of human activity which is most likely to be affected by climate change (Rosenzweig et al. 2014). This assessment is based on a globally consistent protocol-based, multi-model which indicates strong negative effects of climate change particularly where there are high levels of warming at low latitudes where developing countries are concentrated. The urgency of this situation is further emphasised by the large scale meta-analysis by Challinor et al. (2014) showing the relationship between rising temperatures and declining crop yields in coming decades. The use of nitrogen fertilization will have particular relevance in mitigating some of these effects. In this process, compounds such as calcium cyanamide, which encourage natural soil microbial anatgonisms towards 
plant pathogenic organisms and have limited environmental impact could offer considerable benefits for crop husbandry.

\section{ACKNOWLEDGEMENTS}

Grateful thanks are given to the referees and editors for their helpful and constructive comments which have improved this review. Thanks are also given to Mr Paul Corfield and Dr Hans-Juergen Klasse for supplying information.

\section{REFERENCES}

AliX, K., Lariagon, C., Delourme, R. \& Manzanares-DauleuX, M. J. (2007). Exploiting natural genetic diversity and mutant resources of Arabidopsis thaliana to study the $A$. thaliana-Plasmodiophora brassicae interaction. Plant Breeding 126, 218-221.

Allison, F. E. (1924). The effect of Cyanamid and related compounds on the numbers of microorganisms in soil. Journal of Agricultural Research 28, 1159-1166.

Alvarez-Solis, J. D. \& Anzuetto-Martinez, M. de J. (2004). Soil microbial activity under different corn cropping systems in the Highlands of Chiapas, Mexico. Agrociencia (Montecillo) 38, 13-22.

AMBERger, A. (1986). Potential of nitrification inhibitors in modern fertiliser management. Zeitschrift Pflanzenernähr Bodenkde 149, 469-484.

AMBERGER, A. (1989). Research on dicyandiamide as a nitrification inhibitor and future outlook. Communications in Soil Science and Plant Analysis. 20, 1933-1955.

ANON (1853). The disease of finger and toe in turnips. Transactions of the Highland and Agricultural Society of Scotland 3, 118-140.

ANON (1996) Federal Government position paper on the decision of the Bundesrat on the decree amending fertiliser regulations. Berlin: Federal Ministry of Food, Agriculture and Forestry, Berlin letter of March $25^{\text {th }} 1996$, reference: $312-3132 / 23$.

ANON (2008a). 100 years of calcium cyanamide from Trostberg. Monatschift Magazin für den Gartenbau-Profi (Magazine for Professional Horticulture). August issue, pages 296297.

ANON (2008b) United Nations Food \& Agriculture Organisation (FAO) Rome Italy http://www.fao.org/agriculture/crops/thematic-sitemap/theme/spi/soil-biodiversity/thenature-of-soil/what-is-a-healthy-soil/en/ website checked 24 March 2016.

ANON (2012) Brassica Research News no 1. Stoneleigh, Warwickshire: Horticultural Development Company (HDC, now Agriculture \& Horticulture Development Board 

AHDB - Horticulture) and Brassica (now British) Growers Association (BGA). June 3 pages.

Antille, D. L., Gallar, L., Miller., P. C. H. \& Godwin, R. J. (2015). An investigation into the fertiliser particle dynamics off-the-disc. Applied Engineering in Agriculture 31, 49-60.

Apaydin, A., Deligöz, I., KAR, H., KibAR, B. \& KarAagaC, O. (2010). An investigation on clubroot disease (Plasmodiophora brassicae Wor.) races in the Black Sea Region of Turkey. Zirat Fabrikasi Dergisi 28, 57-60.

Arie, T., Kobayashi, G., OKada, G., Kono, Y. \& Yamaguchi, I. (1998). Control of soil borne clubroot disease of cruciferous plants by epoxydon from Phoma glomerata. Plant Pathology 47, 741-748;

Ashby, S. F. (1905). Note on the fate of calcium cyanamide in the soil. Journal of Agricultural Science 1, 358-360.

BAUCHHENB, J. (1994). Influence of Alzodef and Perlka on earthworms (Einflub von Alzodef und Perlka auf Regenwürmer). Freising, Germany: Report KA-187, Bayerische Landesanstalt für Bodenkultur.und Planzenbau.

Belec, C., Trembaly, N. \& Coulombe, J. (2004). Liming and calcium cyanamid for clubroot control in cauliflower. Acta Horticulturae 635, 41-46.

Bell, M. A., Fischer, R. A., ByerleE, D. \& SAYre, K. (1995). Genetic and agronomic contribitions to yield gains: a case study for wheat. Field Crops Research 44, 55-65.

BENYUE, Z. (1995). Research on efficacy of LN fertiliser with chemical function of controlling Chinese cabbage clubroot. Journal of Agricultural Science of Zhejang University 6, 300-301.

BJÄLFVE, G. (1957). The nitrification of calcium cyanamide and its effects on the soil microflora. Annals of the Agricultural College of Sweden (Kungliga Lantbrukshögskolans Annaler) 23, 423-456.

BLETOS, F. A. (2006). Grafting and calcium cyanamide as alternatives to methyl bromide for greenhouse eggplant production. Scientia Horticulturae 107, 325-331.

Bollag, J. M., Senesi, N., HuANG, P.M. (1992). Interactions between soil minerals and microorganisms: impact on the terrestrial ecosystem. New York: Marcel Dekker pages 307-379.

Borneman, J. \& TRIPLETT, E. W. (1997). Molecular microbial diversity in soil from Eastern Amazonia: evidence of unusual micro-organisms and microbial population shifts associated with deforestation. Applied Environmental Microbiology 63, 2647-2653.

Bosch, M \& AMBERGER, A. (1983). Influence of long-term fertilising with different forms of nitrogen fertiliser on $\mathrm{pH}$, humic fractions, biological activity and dynamics of nitrogen of an arable brown earth (Einflub langjähriger Düngung mit verschiedenen $\mathrm{N}$ - formen auf pH-Wert, Humusfraktionen, bilogische Aktivität und Stickstoffdynamik einer AckerBraunerde). Zeitschrift. Pflanzenernähr Bodenkde 146, 714-724.

Bourbos, V. A., Skoudridakis, M. T., Darakis, G. A. \& Koullizakis, M. (1997). Calcium cyanamide and soil solarisation for the control Fusarium solani f. sp. cucurbitae in greenhouse cucumber. Crop Protection 16, 383-386. 
BRAUn, J. von (2010). Strategic body needed to beat food crisis. Nature (London) 465, 548549.

BRONICK, C. J. \& LAL, R. (2005). Soil structure and management: a review. Geoderma 124, $3-22$.

Broughton, W. J. (editor). Nitrogen Fixation vol 1 Ecology (1981); vol 2 Rhizobium (1982); vol 3 Legunes (1983); Broughton, W .J. \& Pühler, S. Nitrogen Fixation vol 4 Molecular Biology (1986). Oxford: The Clarendon Press.

Bruggen, A. H. C van, Semenov, A. M., Diepeningen, A. D. van, Vos, O. J. De. \& Blok, W. J. (2006). Relation between soil health, wave-like fluctuations in microbial populations and soil-borne plant disease management. European Journal of Plant Pathology 115, 105-122.

BUCZACKI, S.T \& CADD, S. E. (1976). Glasshouse evaluation of systemic compounds, derivatives of dithiocarbamic acid and other fungicides for the control of clubroot. Annals Applied Biology 84, 43-50.

Buczacki, S. T. \& Moxham, S. E. (1983). Structure of the resting spore wall of Plasmodiophora brassicae revealed by electron microscopy and chemical digestion. Mycological Research (formerly the Transactions of the British Mycological Society) 81, 221-231.

Burki, F., Kudryavtsev, A., Matz, M. V., Aglyamova, G. V., Bulman, S., Fiers, M., KeEling, P. J. \& PAWlowski, J. (2010). Evolution of Rhizaria: new insights from phylogenomic analysis of uncultivated protists. BioMed Central Evolutionary Biology, 10 no $377,1-18$.

Burns, I. G., Hammond, J. P. \& White, P. J. (2010). Precison placement of fertiliser for optimising the early nutrition of vegetable crops - a review of the implications for the yield and quality of crops and their nutrient use efficiency. Acta Horticulturae 852, 177187.

Campbell, R. N. Greathead, A. S. Myers, D. F. \& Boer, G. J. de (1985). Factors related to control of clubroot of crucifers in the Salinas Valley of California. Phytopathology 75, 665-670.

ChaI, A. L., XIE, X. W., ShI, Y. X. \& LI, B. J. (2014). Research status of clubroot (Plasmodiophora brassicae) on cruciferous crops in China. Canadian Journal Plant Pathology 36 (S1), 142-153.

Challinor, A. J., Watson, J., Lobell, D. B., Howden, S. M., Smith, D. R. \& Chetri, N. (2014). A meta-analysis of crop yields under climate change and adaptation. Nature Climate Change 4, 287-291.

Colhoun, J. (1958). Club root disease of crucifers caused by Plasmodiophora brassicae Woron.--a monograph. Phytopathological Paper no 3, Kew, Surrey: The Commonwealth Mycological Institute.

Cook, W. R. I. (1933). A monograph of the Plasmodiophorales. Archive für Protistenkunde Editors Max Hartmann \& Adolf Pascher Bond 80 Heft 2 S 179-356, Verlag von Gustav Fischer, Jena, Germany.

CORnForth, I. S. (1971). Calcium cyanamide in agriculture. Soils and Fertilisers 34, 463468.

CROOKES, W. (1900). The wheat problem. London: John Murray. 
Crowther, E. M. \& Richardson, H. L. (1932). Studies on calcium cyanamide. 1. The decomposition of calcium cyanamide in the soil and its effects on germination, nitrification and soil reaction. Journal of Agricultural Science 22, 300-334.

Diederichsen, E. Frauen, M. \& Ludwig-Muller, J. (2014). Clubroot disease management challenges from a German perspective. (Special Issue: Clubroot (Plasmodiophora brassicae) on canola and other brassica species: disease development, epidemiology and management.) Canadian Journal of Plant Pathology 36(Suppl. 1), 8598.

DIXON, G. R. (2006). The biology of Plasmodiophora brassicae Wor. - a review of recent advances. Acta Horticulturae 706, 271-282.

DiXON, G. R. (2007). Vegetable brassicas and related crucifers. Crop Production Science in Horticulture no 14. Wallingford, Oxon CAB International.

Dixon, G. R. (2009a). Calcium cyanamide -100 years of successful integrated control. Plant Protection Science 45, 37-38.

DixOn, G. R. (2009b). The occurence and impact of Plasmodiophora brassicae and clubroot disease. Journal of Plant Growth Regulation 28, 194-202.

DiXON, G. R. (2009c). Plasmodiophora brassicae in its environment. Chapter 3 In; Plasmodiophora brassicae (Clubroot)-a plant pathogen that alters host growth and productivity. (Ed. G. R. Dixon). Journal of Plant Growth Regulation 28, 193-303.

Dixon, G. R. (2009d). The impact of climate and global change on crop production. Chapter 17 pages 307-324 In: Climate Change: Observed Impacts on Planet Earth. (Editor T. M. Letcher). Oxford: Elsevier.

DiXON, G. R. (2010). Calcium and pH as parts of a coherent control strategy for clubroot disease (Plasmodiophora brassicae). Acta Horticulturae 867,151-156.

DiXON, G R (2012a). Calcium cyanamide-a synoptic review of an environmentally benign fertiliser which enhances soil health. Acta Horticulturae 938, 211-217.

DIXON, G. R. (2012b). The impact of global climate change on plant disease and world food production. Canadian Journal of Plant Pathology 34, 362-379..

DIXON, G. R. (2014). Clubroot (Plasmodiophora brassicae Woronin) - an agricultural and biological challenge worldwide. Canadian Journal of Plant Pathology 36 (S1), 5-18.

DIXON, G R (2015). Water Irrigation and plant disease. CAB Reviews: Perspectives in Agriculture, Veterinary Science, Nutrition and Natural Resources. CAB Reviews 2015, 10, 009, pages 1-18.

Dixon, G. R. Brokenshire, T. (1981). Chemical control of clubroot (Plasmodiophora brassicae). Crop protection in Northern Britain. Proceedings of a conference held at Dundee University 17-19 March 1981. 325-329. Farnham: The British Crop Protection Council.

DixOn, G. R. \& TILSTON, E. L. (2010). Soil-borne pathogens and their interaction with the soil environment. Chapter 6 pages 197-272 In: Soil Microbiology and Sustainable Crop Production (Editors G. R. Dixon \& E. L. Tilston), Dordrecht, The Netherlands: Springer Publications.

DixON, G. R. \& WALSH, U. F. (1998). Suppression of plant pathogens by organic extracts - a review. Acta Horticulturae 469, 383-390. 
Dixon, G. R. \& Webster, M. A. (1988). Antagonistic effects of boron, calcium and $\mathrm{pH}$ on pathogenesis caused by Plasmodiophora brassicae Woronin (clubroot)-a review of recent work. Crop Research 28, 83-95.

DiXON, G.R. \& WiLLIAMSON, C.J. (1985). Factors affecting the use of calcium cyanamide for control of Plasmodiophora brassicae. Proceedings Better Brassicas 1984 Conference, St. Andrews. Dundee: Scottish Crop Research Institute, (now the James Hutton Institute), 238-244.

DiXon, G. R. \& Wilson, F. (1983). Evaluation of calcium cyanamide for control of Plasmodiophora brassicae (clubroot). Annals of Applied Biology 102(Suppl.), 50-51.

DiXon, G. R. NAiki, T. Webster, A. \& Wilson, F. (1987). Integrated use of boron, calcium cyanamide and nitrogen for control of clubroot (Plasmodiophora brassicae). Crop Protection in Northern Britain 399-404. Farnham: The British Crop Protection Council.

Donald, E. C. LAwrence, J. M. \& Porter, I. J. (2004). Influence of particle size and application method on the efficacy of calcium cyanamide for control of clubroot of vegetable brassicas. Crop Protection 23, 297-303.

DonAlD, E. C. \& PORTER, I.J. (2014). Clubroot in Australia: the history and impact of Plasmodiophora brassicae in brassica crops and research efforts directed towards its control. Canadian Journal of Plant Pathology 36 (S1) 66.84.

DONALD, E. C. \& PORTER, I. J. (2004). A sand-culture technique used to observe the effect of calcium and $\mathrm{pH}$ on root hair and cortical stages of infection by Plasmodiophora brassicae. Australasian Plant Pathology 33, 585-589.

Donald, E. C., Porter, I. J., Faggian, R. \& Lancaster, R. A. (2006). An integrated approach to the control of clubroot in vegetable brassica crops. Acta Horticulturae 706, 283-300.

Donaldson, S P. \& DeACON, J. W. (1993). Changes in motility of Pythium zoospores induced by calcium and calcium-modulating drugs. Mycological Research 97, 877-883.

Doran, J. W., Sarrantonio, M. \& Liebig, M. A. (1996). Soil health and sustainability. Advances in. Agronomy 56, 2-54.

DORAN, J. W. \& ZEISS, M. R. (2000). Soil health and sustainability: managing the biotic component of soil quality. Applied Soil Ecology 15, 3-11.

EINHORn, G., Bochow, H., Huber, J. \& KrebS, B. (1991). Methodological studies on the detection of antagonists of the clubroot pathogen Plasmodiophora brassicae Wor. Archive für Phytopathologie und Pflanzenschutz 27, 205-208.

ERnst, F A (1928). Fixation of atmospheric nitrogen. London: Chapman \& Hall, New York: van Norstrand Inc.

EveILlaRD, E. (2005). Improve mineral N efficiency to protect the environment : the French experience. UNIFA union des Industries de la Fertilisation. 92909 Paris La Défense Cedex.

Fletcher, J. T., Hims, M. J., ArCher, F. C. \& Brown, A. (1982). Effects of adding calcium and sodium salts to field soils on the incidence of clubroot. Annals of Applied Biology 100, 245-251. 
FRANK, A. (1908). Chemical industry in relation to agriculture. Journal of the. Society for Chemical Industry 27, 1093-1100.

Frank, D. A. \& Groffman, P. M. (2009). Plant rhizospheric N processes: what we don't know and why we should care. Ecology 90, 1512-1519.

Garbeva, P., Veen, J. A. van, \& Elsas, J. D. van (2004). Microbial diversity in soil: selection of microbial populations by plant and soil type and implications for disease suppression. Annual Review of Phytopathology 42, 243-270.

GarretT, D (1958). The biology of root invading fungi. Cambridge \& London: Cambridge University Press.

GREENWOOD, D. J. (1982). Nitrogen supply and crop yield: the global scene. Plant and Soil 67; 45-59.

GiAnQuinto, G., SAMBO, P. \& BonA, S. (2003). The use of SPAD-502 chlorophyll meter for dynamically optimising the nitrogen supply in potato crop: a methodological approach. Acta Horticulturae 627, 217-224.

GÜTHNER, T. \& MERTSCHENK, B. (2006). Cyanamides. In: Ullman's Enclyclopedia of Industrial Chemistry (100 Years). Wiley on line Library published 15th July 2006. DOI: 10.1002/14356007.a08_139.pub2 (tested 4th November 2015) Wiley-VCH Verllag $\mathrm{GmbH} \& \mathrm{Co}, \mathrm{KgaA}$.

HAENSEleR, C. M. \& MoYeR, T. R. (1937). Effect of calcium cyanamide on the soil microflora with special reference to certain plant parasites. Soil Science 43, 133-152.

Hall, A. D. (1905). Calcium cyanamide. Journal of Agricultural Science, Cambridge 1, 146148.

HARLING, R \& OXLEY, S. (2007). Clubroot disease of oilseed rape and other brassica crops. Technical Note TN 602, Edinburgh: Scottish Agricultural College.

Harling, R., Stewart, K. \& Gladders, P. (2007). Clubroot control using novel and sustainable methods. Project report (HH322TFV), London: Department for the Environment, Food and Rural Affairs (Defra).

HaRtwig, N. L. \& Amoon, H. V. (2002). Cover crops and living mulches. Weed Science 50, 688-699

Hinsinger, P., Gobran, G. R., Gregory, P. J. \& Wenzel, W. W. (2005). Rhizosphere geometry and heterogeneity arising from root-mediated physical and chemical processes. New Phytologist 168, 293-303.

Horiuchi, S. Hori, M. TAKashi, S. Shimizu, K. (1983). Factors responsible for the development of clubroot-suppressing effect in soil solarization. Bulletin of the Chugoku National Agricultural Experiment Station, E 20,25-48. .

HSEIH, W-H. \& WANG J-F. (1986). Investigations on suppressive soils of clubroot of crucifers in Taiwan. Plant Protection Bulletin (Taiwan R.O.C.) 28, 353-362.

HuANG, H. C. \& Sun, S.K. (1991). Effects of S-H mixture or Perlka ${ }^{\mathrm{TM}}$ on carpogenic germination and survival of sclerotia of Sclerotinia sclerotiorum. Soil Biology and Biochemistry 23, 809-813.

Humpherson-Jones, F. M. Dixon, G. R. Craig, M. A. \& Ann, D. M. (1992). Control of clubroot using calcium cyanamide - a review. Brighton Crop Protection Conference, Pests and Diseases 3, 1147-1154. 
Jacob, K. D., Allison, F. E. \& Braham, J. M. (1924). Chemical and biological studies with Cyanmid and some of its transformation products. Journal of Agricultural Research $\mathbf{2 8}$, 37-69.

JONES, D. \& GRAY, E. G. (1973). Factors affecting the germination of sclerotia of Sclerotinia sclerotiorum from peas. Mycological Research (formerly Transactions of the British Mycological Society) 60, 495-500.

Junwei, M. A., Wanchun, S. U. N., QIaOgang, Y. U., QIAng, F. U. \& Jianrong, F. U. (2013). Effects of cyanamide fertiliser on microbial community structure of continuous cropping soil. Journal of Zhejiang University (Agriculture \& Life Sciences) 39, 281-290.

Kamo, T., HiRAdate, S. \& FuJII, Y. (2003). First isolation of natural cyanamide as a possible allelochemical from hairy vetch (Vicia villosa). Journal of Chemical Ecology 29, 275283.

Kamo, T., Sato, M., Kato, K., Hiradate, S., Nakajima, E., Fujil, Y. \& Hirota, M. (2006). Quantification of cyanamide contents in herbaceous plants. Bioscience Biotechnology and Biochemistry 70, 2310-2312.

Kamo, T., TAkemura, T., Wasano, N., FujiI, Y. \& Hiradate, S. (2012). Quantification of cyanamide in young seedlings of Vicia species, Lens culinaris and Robinia pseudoacacia by gas chromatography-mass spectrometry. Bioscience Biotechnology and Biochemistry 76, 1416-1418.

KARLING, J. S. (1968). The Plasmodiophorales - including a complete host index, bibliography and a description of diseases caused by species of this order. New York and London: Hafner Publishing Company.

KIRKBY, E. A. (1968). Influence of ammonia and nitrate nutrition on the cation-anion balance and nitrogen and carbohydrate metabolism of white mustard plants grown in dilute nutrient solutions. Soil Science 105, 133-141.

KLASSE, H. J. (1996). Calcium cyanamide-an effective tool to control clubroot-a review. Acta Horticulturae 407, 403-409.

KLASSE, H. J. (1999). Calcium cyanamide-a unique source of nitrogen promoting healthy growth and improving crop quality of vegetables. Improved crop quality by nutrient management 233-235. .

KLASSE, H.J. (2002). Calcium cyanamide-an important tool in methyl bromide replacement strategies. Germany: Sud-deutsch Kalkstickstoorf Werke (SKW) Trostberg AG.

KuEN, J. \& DRECKSEl, O. (1928). Der Einfluss der Kalkstickstorf auf des Bacterienleben in Boden. Zietschrift für Pflansenernähr Düngung und Bodenkde 7, 105-118.

LAHLALI, R. \& PENG, G. (2014a). Suppression of clubroot by Clondrostachys rosea via antibiosis and induced host resistance. Plant Pathology 63, 447-455.

Lahlali,R. L.,, McGregor, L., Song, T., Gossen, B. D., Narisawa, K. \& Peng, G. (2014b). Heteroconium chaetospira suppresses clubroot by inducing host resistance via ethylene, jasmonic acid and auxin pathway signalling. PLOSONE P4: e94144, 1-9.

LEHMANN, J. \& KLEBER, M. (2015). The contentious nature of soil organic matter. Nature (London) 528 , 60-68. 
Lehtovirta-Morley, L. E., Stoecker, K., Vikinskas, A., Prosser, J. I. \& Nicol, G. W. (2011). Cultivation of an obligate acidophilic ammonia oxidiser from a nitrifying soil. Proceedings of the National Academy of Science (PANS) 108 (380), 15892-15897.

LEIGH, G. J. (2004). The World's Greatest Fix-a history of nitrogen and agriculture, chapter 5. In: The Triumph of Industrial Chemistry. Oxford: Oxford University Press.

Liesach, W., Janssen, P. H., Rainey, F. A., Ward-Rainey, N. L. \& Stackebrandt, E. (1997). Microbial diversity in soil: the need for a combined approach using molecular and cultivation techniques. In: Modern Soil Microbiology,(Editors J. D. van Elas \& J. T. Trevors) New York USA: Marcel Dekker.

LINDE, C. P. (1916) Aus meinem Leben und von meiner Arbeit. Munich: R. Oldenbourg.

Macfarlane, I. (1958). A solution-culture technique for obtaining root-hair or primary, infection by Plasmodiophora brassicae. Journal of General Microbiology 18, 720-732.

MaIER-Greiner, U. H., Obermaier-SKrobraner, M. M., Estermaier, L. M., Kammerloher, W., Freund, C., WÜlfing, C., Burkert, U. I., Mattern, D. H., Breuer, M., Eulitz, M., Küfrevioglu, O. F. \& Hartmann, G. R. (1991). Isolation and properties of a nitrile hydratase from the soil fungus Myrothecium verrucaria that is highly specific for the fertiliser cyanamide and cloning of its gene. Proceedings of the National Academy of Science 88, 4260-4264.

MARsChner, J., RÖMHELD, V., Horst, W. J. \& MARTIN, P. (1986). Root-induced changes in the rhizosphere: importance for mineral nutrition of plants. Zeitschrift für Pflanzenernähr 149, 441-456.

Martin, W. H. (1933). Plant Pathology. Report of New Jersey Agricultural Experimental Station for the 2-year period ending June 30 1933, 57-66.

MAttey, M. \& Dixon, G. R. (2015). Premature germination of resting spores as a means of protecting brassica crops from Plasmodiophora brassicae Wor., (Clubroot). Crop Protection 77, 27-30.

Mazzola, M. (2004). Assessment and management of soil microbial community structure for disease suppression. Annual Review of Phytopathology 42, 35-59.

McDonald, M. R. Kornatowska, B. \& McKeown, A. W. (2004). Management of clubroot of Asian Brassica crops grown on organic soils. Acta Horticulturae 635, 2530.

MCDONALD, M. R. (2002). Improved management of clubroot in crucifer crops - Report 2002. University of Guelph, Muck Crops Research Station, Ontario L7B 0E9. http://www.uoguelph.ca/muckcrop/ (url checked 15 March 2016).

MELLOR, J. W. (1925). A comprehensive treatise on inorganic and theoretical chemistry. In 16 volumes published 1922-1937 of which volume 5 deals with nitrogen fixation. London: Longmans.

MiRANDA, V. H. B. (1975). Influence of nitrogenous fertilisers upon some soil characterisitics. Landwirtschaftliche Forschung 29, 21-27.

MÜLLER, H. (1955). Untersuchungen über die Wirkung des Cyanamids im Kalkstickstoff auf pathogene und nichpathogene Mikroorganismen des Bodens. Archive für Mikrobiologie 22, 285-306. 
MuKERJI, B. K. (1932). Studies on calcium cynamaide. II. Microbiological aspects of nitrification in soils under varied environmental conditions. Journal of Agricultural Science 22, 335-347.

Murakami, H. Tsushima, S. Kuroyanagi, Y. \& Shishido, Y. (2002). Reduction of resting spore density of Plasmodiophora brassicae and clubroot disease severity by liming. Soil Science and Plant Nutrition 48, 685-691.

MYeRs, D. C, \& CAMPBELL, R.N. (1985). Lime and the control of clubroot of crucifers: effects of $\mathrm{pH}$, calcium, magnesium, and their interaction. Phytopathology 75, 670-673.

NAIKI, T. \& DiXON, G. R. (1987). The effects of chemicals on developmental stages of Plasmodiophora brassicae (clubroot). Plant Pathology 36; 316-327.

Naiki, T., Kageyama, K. \& IKegami, H. (1978). The relation of spore density of Plasmodiophora brassicae Wor., to root hair infection and club formation in Chinese cabbage (Studies on the clubroot of cruciferous plant II). Annals of the Phytopathology Society of Japan 53, 432-439.

Neuhauser, S., Kirchmair, M. \& Gleason, F. H. (2011). The ecological potential of Phytomyxea (plasmodiophorids) in acquatic food webs. Hydrobiologia 659, 23-35.

Newton, A. C., Fitt, B. D. L., Atkins, S. D., Walters, D. R. \& Daniell, T. J. (2010). Pathogenesis, parasitism and mutualism in the trophic space of microbe-plant interactions. Trends in Microbiology 18, 365-373.

Niwa, R., KumeI, T., Nomura, Y., Yoshida, S., OsaKi, M. \& EZAWA, T. (2007). Increase in soil $\mathrm{pH}$ due to $\mathrm{Ca}$-rich organic matter application causes suppression of the clubroot disease of crucifers. Soil Biology \& Biochemistry 39, 778-785.

Niwa, R., Nomura, Y., Osaki, M. \& EzaWA, T. (2008). Suppression of clubroot disease under neutral $\mathrm{pH}$ caused by inhibition of spore germination of Plasmodiophora brassicae in the rhizosphere. Plant Pathology 57, 443-452.

Nõmmik, H. (1958). On decomposition of calcium cyanamide in the soil. Acta Agriculturae Scandinavica 8, 404-440.

PAGE, L. V. (2001). Studies of components for a potential integrated control system for Plasmodiophora brassicae. Ph. D, thesis, University of Strathclyde, Glasgow;

Pankhurst, C., Doube, B. M. \& GuPTA, V. V. S. R. (1997). Biological Indicators of Soil Health: synthesis. In Pankhurst, C. E., Doube, B. M. \& Gupta, V. V. S. R. (editors.) pages 419-435. Biological indicators of soil health Oxford: CAB International.

Paustian, K., Lehmann, J., Ogle, S., Reay, D., Robertson, G. P. \& Smith, P. (2016). Climate-smart soils. Nature 532, 49-57.

PIMPINI, F., VENTER, F. \& WÜNSCH, A. (1970). The influence of different nitrogen forms and increasing nitrogen doses on the content of total nitrogen and of nitrate in cauliflower plants. Landwirtschaftliche Forschung 23, 363-370.

Pleysier, L., ArorA, Y. \& JuO, A. S. R. (1987). Nitrogen leaching and uptake from calcium cyanamide in comparison to urea and calcium ammonium nitrate in an ultisol from humid tropics. Nutrient Cycling in Agroecosystems 12, 193-199.

RAAiJMakers, J. M. \& MAZzola, M. (2016). Soil immune responses. Science 352, 1392 1393.

Raaimakers, J. M., Paulitz, T. C., Steinberg, C., Alabouvette, C. \& Mö̈mmeLocCOZ, Y. (2009). The rhizosphere: a playground and battlefield for soilborne 
pathogens and beneficial organisms. 341-361 In: Rhizosphere: achievements and challenges, (Eds Y. Dessaux, P. Hinsinger \& P. Lemanceau). Plant and Soil 321 (1 \&2), $1-535$.

RatHSACK, K. (1978). Die nitrificide Wirkung des Dicyanamides. Landwirtschaftliche Forschung 31, 347-358.

RIEDER, G. (1981) Calcium cyanamide-fertiliser or pesticide? World Crops, January issue.

Rosenzweig, C., Elliott, J., Deryng, D., Ruane, A. C., Müller, C., Arneth, A., Boote, K. J., Folbeth, C., Glotter, M., Khabarov, N., Neumann, K., Piontek, F., Pugh, T. A. M., Schmid, E., Stehfest, E., Yang, H. \& Jones, J. W. (2014). Assessing agricultural risks of climate change in the $21^{\text {st }}$ century in a global gridded crop model intercomparison. Proceedings of the National Academy of Sciences (PNAS). 111, 32683273.

Rouxel, F., BRiard, M. \& Lejeune, B. (1985). Studies of soil receptiveness to clubroot caused by Plasmodiophora brassicae: experiments on reponses of a series of vegetable soils in Brittany. Progress on pest management of field vegetables. Proceedings of the CEC/IOBC Experts' Group, Rennes, France 20-22 November 1985. (Editors R Cavallorao \& C J Pelerents). Pages 145-152. Rotterdam, The Netherlands: A A Balkema. Roy, A. H. (2015). Global fertiliser industry: transitioning from volume to value. Proceedings of the International Fertiliser Society, booklet no 769, 1-24.

Schutter, M., SAndeno, J. M., \& Dick, R. P, (2001). Seasonal, soil type, alternative management influences on microbial communities of vegetable cropping systems. Biology and Fertility of Soils 34, 397-410.

Schwelm, A., Fogelqvist, J., Knaust, A., JÜlke, S., Lija, T., Bonilla-Rosso, G., Karlsson, M., Shevchenko, A., Dhandapani, V., Choi, S. R., Kim, H. G., Park, J. Y., Lim, Y. P., Ludwig-Müller, J \& Dixelius, C. (2015). The Plasmodiophora brassicae genome reveals insights in its life cycle and ancestry of chitin synthases. Nature Scientific Reports Srep 5, no 11153, 1-12. http://www.nature.com/scientificreports . (url checked 26 July 2016).

ShI, K., WANG, L., ZHOU, Y-H., YU, Y-L. \& YU, J-Q. (2009). Effects of calcium cyanamide on soil microbial communities and Fusarium oxysporum f. sp. cucummerinum. Chemosphere 75, 872-877.

SiELING, K. \& KAGE, H. (2010). Efficient N management using winter oilseed rape: A review. Agronomy and Sustainable Development. 30, 271-279.

SMITH, A. M. (1961). Calcium cyanamide. Manures and Fertilisers pages 115-117. London: Thomas Nelson \& Sons Ltd.

SmIL, V. (2004). Enriching the Earth: Fritz Harber, Carl Bosch, and the transformation of world food production. Massachusetts Institute of Technology (MIT) Press, Cambridge Massachusetss.

Solomon, S., Qin, D., Manning, M., Marquis, M., Avery, T. K., Tignor, M. M. B., MilleR, Jr H. L. \& CHEN, Z. (2007). The physical science basis: contributions of Working Group 1 to the Fourth Assessment Report of the Intergovernmental Panel on Climate Change. Cambridge University Press, Cambridge.

STEWART, K. (2007). Clubroot control in Brassicas using novel and sustainable methods. $\mathrm{PhD}$ Thesis, University of Edinburgh. 
STRANSKY, H. \& AMBERGER, A. (1973). Isolation and properties of a cyanamide hydratase (EC 4.2.1) from Myrothecium verrucaria. Zeitschrift Pflanzenphysiologie 70, 174-187.

Strelkov, S. E. \& Dixon, G. R. (2014). Clubroot (Plasmodiophora brassicae) on canola and other brassica species - disease development, epidemiology and management. Canadian Journal of Plant Pathology 36 (S1), 1-4.

StURKIE, D. G. (1937). Control of weeds in lawns with calcium cyanamide. Journal American Society of Agronomy, 29, 802-807.

TAKahashi, H., IshiKawa, T., Kaido, M., TAKita, K., Hayakawa, T., OKAZAKi, K., ITOH, K., Mitsui, T. \& HoRI, H. (2006). Plasmodiophora brassicae-induced cell death and medium alkalisation in clubroot-resistant cultured roots of Brassica rapa. Journal of Phytopathology 154, 156-162.

Takahashi, H., TAKita, K., Kishimoto, T., Mitsui, T. \& HoRI, H. (2002). Ca2+ is required by clubroot resistant turnip cells for transient increases in PAL activity that follows inoculation with Plasmodiophora brassicae. Journal of Phytopathology 150, 529-535.

Tewari, K., Suganuma, T., Fuijikake, H., Ohtake, N., Sueyoshi, K., Takahashi, Y. \& OHYAMA, T. (2004). Effect of deep placement of $\mathrm{N}$ fertilisers and different inoculation methods on bradyrhizobia on growth, $\mathrm{N}$-fixation activity and $\mathrm{N}$-absorption rate of fieldgrown soybean plants. Journal of Agronomy and Crop Science 190, 46-58.

Thorman, R. E., Williams, J. R., Musselbrook, T. H., Rollett, A. J., Bowden, A., Dhrosbree, A. \& Chambers, B. J. (2014). Nitrification inhibitor and nitrogen fertiliser application timing strategies to reduce nitrous oxide emissions from winter wheat land. The Proceedings of the 18th Nitrogen Workshop - The nitrogen challenge: building a blueprint for nitrogen use and efficiency and food supply, Lisbon, Portugal 30th June to 3rd July 2014, ppages 521-523. pdf available from CAB Abstracts, Wallingford, Oxon.

Tian, Y., Zhang, X., LiU, J., Chen, Q. \& GaO, L. (2009). Microbial properties of rhizosphere soils as affected by rotation, grafting and soil sterilisation in intensive vegetable production. Scientia Horticulturae 123, 139-147.

Tollefson, J. (2010). Intensive farming may ease climate change. Nature (London) $\mathbf{4 6 5}$, 853.

TOORsviK, V., GoKsoyr, J. \& DANe, F. D. (1990). High diversity in DNA of soil bacteria. Applied Environmental Microbiology 56, 782-787.

Tourna, M., Steiglmeier, M., Sprang, A., KÖnneKe, M., Schintimeister, A., Ulrich, T., Engel, M., Schloter, M., Wagner, M., Richter, A. \& Schleper, C. (2011). Nitrososphare viennensis, an ammonia oxidising archaeon from soil. Proceedings of the National Academy of Sciences (PNAS) 108, 8420-8425

Tremblay, N. Belec, C. Coulombe, J. \& Godin, C. (2005). Evaluation of calcium cyanamide and liming for control of clubroot disease in cauliflower. Crop Protection 24, 798-803.

Vallad, G. E. \& Goodman, R. M. (2004). Systemic acquired resistance and induced systemic resistance in conventional agriculture. Crop Science 44, 1920-1934.

VERONA, O. (1970). The effect of calcium cyanamide on some groups of lower fungi [Der Einfluss des Kalkstickstoffs auf einige Gruppen von niederen Pilzen]. Landwirtschaftliche Forschung 23, 36-50. 
1101

1102

1103

1104

1105

1106

1107

1108

1109

1110

1111

1112

1113

1114

1115

1116

1117

1118

1119

1120

1121

1122

1123

1124

1125

1126

1127

1128

1129

1130

1131

1132

1133

1134

1135

1136

1137

1138

1139

1140

1141

1142

VILSMEIER, K. \& AMBERGER, A. (1978). Model experiments concerning the breakdown of powdered and granulated calcium cyanamide fertilisers. Journal of Agronomy and Crop Science 147, 68-77.

WALKER, J. C. \& LARSON, R. H. (1935). Calcium cyanamide in relation to control of clubroot of cabbage. Journal of Agricultural Research 51, 183-189.

Wall, D. H., NIELSEN, U. N. \& SIX, J. (2015). Soil biodiversity and human health. Nature (London) 528, 69-76.

WAlters, D. R., RAtsep, J. \& HAVIS, N. D. (2013). Controlling crop diseases using induced resistance: challenges for the future. Journal of Experimental Botany 64, 1263-1280.

WANG, J-F. \& HSIEH, W-H. (1986). Studies of suppressive factors and characteristics of suppressive soils of clubroot in crucifers. Plant Protection Bulletin (Taiwan ROC) 28, 363-370.

WeBSTER, M. A. (1986). pH and nutritional effects on infection by Plasmodiophora brassicae Wor. and clubroot symptoms. Ph. D. thesis, University of Aberdeen;

Webster M. A. \& Dixon, G. R. (1991a). Calcium, pH and inoculum concentration influencing colonisation by Plasmodiophora brassicae. Mycological Research . 95, 6473.

Webster, M. A. \& Dixon, G. R. (1991 b). Boron, pH and inoculum concentration influencing colonisation by Plasmodiophora brassicae. Mycological Research 95, 7479.

WiLliamson, C. J. \& DYCE, P. E. (1989). The effect of calcium cyanamide on the reaction of swede cultivars to populations of Plasmodiophora brassicae. Plant Pathology 38, 230238.

Wissuwa, M., Mazzola, M. \& PiCARD, C. (2009). Novel approaches in plant breeding for rhizosphere-related traits. Plant and Soil 321, 409-430.

Wolfe, A. \& Wolfe, G (1930). Ueber den Einfluss des Kalkstickstoffs auf die Mikroflora des Bödens. Centblatt Bakteriologie. (II). 81, 221-230.

Wood, M. (1998). Cah marker gene aids plant transformations. Agricultural Research July issue, 12-13. Swindon: Biotechnology and Biological Research Council.

Woronin, M. S. (1878) Plasmodiophora brassicae-the cause of cabbage hernia, published in Jarbücher für Wissenschaftliche Botanik vol 11 (in German) translated by C. Chupp, published as Phytopathological Classics no 4. St Paul, Minnesota USA: American Phytopathological Society (see page 28).

Yamamoto, A., AkiYama, H., Naokawa, T. \& Yagi, K. (2012). Effect of lime-nitrogen application on $\mathrm{N}_{2} \mathrm{O}$ emmission from an andosol vegetable field. Soil Science and Plant Nutrition, 58, 245-254.

Yamamoto, A., Akiyama, H., NaOKawa, T. \& Yagi, K. (2013). Lime-nitrogen application reduces $\mathrm{N}_{2} \mathrm{O}$ emission from a vegetable field with imperfectly-drained sandy clay-loam soil. Soil Science and Plant Nutrition 59, 442-449.

Yano, S., Tanaka, S., Kameya-Iwaki, M. \& Katumoto, K. (1991). Relation of Ca2+ efflux to germination of resting spores of clubroot fungus. Bulletin of the Faculty of. Agriculture, Yamaguchi University 39, 105-112. 
Yao, H., He, Z., Wilson, M. J., \& CAmpbell, C. D. (2000). Microbial biomass and community structure in a sequence of soils with increasing fertility and changing land use. Microbial Ecology 40, 223-237.

Zhao, Y. X-X., Cheng, Y. T. \& WeI, J. W. (2015). Biocontrol effect of Trichoderma harzianum $\mathrm{T} 4$ on brassica clubroot and analysis of rhizosphere microbial communities based on T-RFLP. Biocontrol Science and Technology 25, 1493-1505.

ZHU, B. L., MA, J. W., YE, X. Z., \& XIA, Z. M. (2001). Effects of lime-nitrogen on soil amelioration and vegetable production (Chinese). Journal of Zheijang University 27, 339-342. 